\title{
The structural equation modeling of reading interest psycho-behavioural constructs: How are they related across different modes of reading?
}

\author{
$*^{1}$ Nur Hidayanto Pancoro Setyo Putro; ${ }^{2}$ Jihyun Lee \\ *Faculty of Languages and Arts, Universitas Negeri Yogyakarta \\ Jl. Colombo No. 1, Depok, Sleman 55281, Yogyakarta, Indonesia \\ *Email: noersabar@yahoo.com
}

Submitted: 03 April 2017 | Revised: 13 May 2017 | Accepted: 13 May 2017

\begin{abstract}
The present study examines the relationships between the psycho-behavioral constructs underlying undergraduate students' reading interest. The a priori framework in conceptualizing the subcomponents of reading interest is based on two modes of reading (printed-text-based and also Internet-based), and three types of psycho-behavioral motives/intentions of reading (affective, cognitive, and behavioral). Participants in this study were students $(M=20.14$ years old) from an Indonesian university $(n=993)$. Exploratory and confirmatory factor analyses show the salience of 10 factors across reading modes and psycho-behavioral domains of reading. The most acceptable SEM models that explore the relationships among the sub-components of reading interest have the student reading interest in the print mode preceded interest in reading online materials. Implications of these findings are discussed for theory development and practice.
\end{abstract}

Keywords: reading interest, affect, cognition, behavior, factor analysis

\section{How to cite item:}

Putro, N. \& Lee, J. (2017). The structural equation modeling of reading interest psycho-behavioural constructs: How are they related across different modes of reading?. REiD (Research and Evaluation in Education), 3(1), 50-63. doi:http://dx.doi.org/10.21831/reid.v3i1.13530

\section{Introduction}

In the past twenty years, there is a growing body of literature suggesting that current young generation has adopted multiple modalities in reading. Much of this work highlighted the increasing practice of reading online materials among school-aged and university students (Coiro \& Dobler, 2007; Karim \& Hasan, 2007; Liu \& Huang, 2008; McKenna, Conradi, Lawrence, Jang, \& Meyer, 2012). Other research revealed the emerging practice of reading from social media platforms, e.g., Facebook and Twitter (Junco, 2012; Kirschner \& Karpinski, 2010). Although these studies have indicated an increasing trend towards reading online materials and social media reading, there is also a large volume of published studies showing reading printed materials has not been completely eclipsed (e.g., Buzzetto-More, Guy, \& Elobaid, 2007; Liu, 2005).

As multimodal literacy becomes more widespread (Walsh, 2010), a great deal of previous research into reading motivation has focused on how frequent access to the Internet is associated with low interest in reading from printed materials and a decline in academic achievement (Alterman, 2007; DeWaal, Schönbach, \& Lauf, 2005; Kirchhoff, 2010; Lee \& Leung, 2008; Mokhtari, Reichard, \& Gardner, 2009). Similarly, there is a growing body of literature suggesting how social media disempower today's youth book reading motivation and lead to low academic achievement (Junco, 2012; Kirschner \& Karpinski, 2010).

While much research has explored the relationships between how the amount of 
time spent on digital reading and the amount of time spent on reading printed books, little is known about how the psycho-behavioural constructs of reading interest within different modes (i.e., printed, online, and social media) are related to one another. Consequently, there is a need to further our understanding of interrelationships among the constructs within reading interest. This study is designed to address this lacuna.

The following sections briefly review some evidence suggesting the relationships among interest in reading in print settings, interest in reading online materials, and interest in social media reading. The first section outlines previous studies indicating the relationships among reading printed materials, reading online materials, and reading social media. The next section of the literature reviews and explores the evidence for interrelationships among the constructs within reading interest. Clearly, this is largely an unexplored area. This brief literature review is then followed by the results from an exploration of the relationships and interrelationships between the dimensions of reading interest, based on the data from 993 undergraduate students from one Indonesian university. The discussion then builds on the findings from both survey analyses and brief review of the literature. It also provides some steps to explore the issues raised further in current thinking and practice.

\section{Relationship between Different Modes of Reading}

Previous research that examined the relationship among reading in printed materials, reading online materials, and reading social media has shown mixed results. Many studies that claimed a close and positive relationship between reading in print settings and reading online materials have made its argument based on the amount of time people spent on reading across different types of settings (OECD, 2011; Veenhof, 2006). For instance, Veenhof (2006) investigated the social impact of the Internet use based on the Statistics Canada 2005 General Social Survey data, and found that readers who spent more time reading from the Internet also spent more time reading printed books. Similarly, the PISA
2009 project (OECD, 2011) also showed that students who read more frequently from online sources also read printed materials more frequently. A study by Tenopir, Volentine, and King (2013) also reported that readers who used social media more frequently also read scholarly materials more frequently.

While much research has shown the close positive relationships between reading patterns involving different modes of reading, other studies demonstrated the contrasting results. When it comes to the time spent on reading, the negative relationship was documented as well between the amount of time spent on reading online materials and that spent on reading printed materials (DeWaal, Schönbach, \& Lauf, 2005; Lee \& Leung, 2008). For instance, the study by Lee \& Leung (2008) investigated the replacement effects of the Internet and found that use of the Internet for reading is negatively related to reading printed newspapers $(r=-.23)$ and magazines $(r=-.39)$, indicating that those who frequently read online are less likely to read printed materials. Another line of studies emphasizing the differences has brought about the widespread trend of reading newspapers online. Online newspapers have now become the preferred news source for young people over the printed newspapers (Alterman, 2007; Kirchhoff, 2010). Together, these studies suggest that there has been some partial shift in the mode of reading from all printed settings to online/digital/social media reading. Young generations, in particular, have adopted reading online materials as an alternative mode to conventional reading in print settings. These studies also indicate that reading can happen in three different formats: print, online, and social media. As such, reading interest in the present study is also investigated from these three modes of reading.

Relationships among the Psycho-Behavioural Constructs of Reading Interest

Following Putro's work (2017), reading interest in the present study is conceptualized to incorporate both mode and psycho-behavioral dimensions (i.e., affective, cognitive, and behavioral). Specifically, Putro (2017) claimed that each of these psycho-behavioral 
dimensions is situated in a particular mode of reading. Interest in reading printed materials involves three psycho-behavioral constructs (i.e., elaboration, enjoyment, and competence experience); interest in reading online materials involves five psycho-behavioral constructs (i.e., value, confidence, enjoyment, competence experience, and flow); and interest in reading social media comprises two psychobehavioral constructs (i.e., sense of belonging and enjoyment). While there have not been systematic reviews or empirical studies that examined the links between all these psychobehavioral constructs of reading interest, the relationships between certain pairs or groups of the constructs (e.g., enjoyment and flow) have been explored and their close - either conceptual or empirical - links have been demonstrated. The following segments provide some evidence on the empirical relationships between the ten constructs of reading interest.

\section{Enjoyment, Flow, and Competence}

There have been few studies conducted (e.g. Shernoff, Csikszentmihalyi, Shneider, \& Shernoff, 2003; Sherry, 2004; Weber, Tamborini, Westcott-Baker, \& Kantor, 2009) which have considered the role of enjoyment and competence/knowledge/cognitive abilities in generating flow experiences. People would experience being completely absorbed in an activity that they find intensely enjoyable (e.g., Shernoff et al., 2003; Sherry, 2004). Without enjoyment, an intense experience of flow is unlikely to occur (Csikszentmihalyi, 1997; Sherry, 2004). Further, in a study by Shernoff, Csikszentmihalyi, Shneider, and Shernoff (2003), it is reported that when students found classroom activities interesting, easy to concentrate, and enjoyable, their flow condition was also high. Some scholars also argue that competence is important to sustain enjoyment and to transfer it to the flow condition (Carroll \& Loumidis, 2001; Csikszentmihalyi, 1997; Sherry, 2004).

\section{Enjoyment, Competence, and Achievement}

While the causal relationships among these constructs are proven to be hard to demonstrate, they are at least interrelated with each other. For example, confidence in per- forming a task can lead to higher competence level but the reverse relationship, i.e., competence leading to feeling confidence, is also highly likely (Clanton et al., 2014; Dunst \& Dempsey, 2007; Pajares \& Johnson, 1994). Not surprisingly, students' self-evaluation of competence is significantly correlated with their achievement and confidence (Pajares \& Johnson, 1994). Examples of domains demonstrating the close relationships of competence, confidence, and achievement are abundant: writing (Pajares \& Johnson, 1994), reading (McGeown et al., 2015), and general cognitive abilities (Stankov \& Lee, 2008).

\section{Enjoyment, Competence, Value, and Achievement}

Many empirical studies have been conducted within the framework of expectancyvalue theory (Eccles, 1983; Wigfield, 1994; Wigfield \& Eccles, 2002; Wigfield \& Tonks, 2002) to investigate how students' enjoyment, values, and perceived competence beliefs are related to academic outcomes attainment. It appears that competence beliefs, enjoyment (intrinsic value), and utility value would positively reinforce each other (Chouinard, Karsenti, \& Roy, 2007; Cocks \& Watt, 2004; Wilson et al., 2008). While the achievementrelated outcomes are employed as the final destination of this achievement-motivational theory, a more realistic picture would include reciprocal relationships (Marsh \& Martin, 2011) among these constructs especially when developmental perspectives (Wigfield \& Eccles, 2002) are taken into account.

\section{Elaboration, Enjoyment, Value, Competency, and Sense of Belonging.}

Empirical studies were able to demonstrate the links between students' use of elaboration strategy in reading and enjoyment in reading (Lau \& Ho, 2016). Even when people read for a targeted purpose (e.g., doing homework, conducting a project), reading with elaboration can be a useful strategy in attaining the goals. The Program for International Student Assessment (PISA) data also showed that students' use of elaboration strategies are positively linked to competency beliefs, anxiety, and interest (Schleicher, 2016); students who use elaboration strategies more frequent- 
ly in their reading reported higher self-competence beliefs in their ability, less anxiety and more interest in reading. Students who are confident in their abilities in learning tended to report using more elaboration strategy as well (Perry \& Smart, 2007). In recent studies people's tendency to use the elaboration strategy were also found to have greater intrinsic motivation, sense of belonging, competence, and autonomy (Sundar, 2015).

A caveat should be registered; it appears that different studies use slightly different labels for the same constructs. In this study, enjoyment and intrinsic value are considered interchangeable, so are relatedness and sense of belonging. Value in this study is referred to the perception of usefulness, i.e., utility value, perceived value, and perceived utility value. Competence means self-beliefs in one's own capability in completing a task, which is also interchangeably used with confidence, competence beliefs, and perceived competence. Experiences of competence are referred to as memories of prior experiences about achievement or mastery of skills or tasks.

\section{Method}

The participants were undergraduate students in an Indonesian university, a medium-sized university with about 25,000 students enrolling in 2014. A total of 993 undergraduate students volunteered to participate in the study. The survey data were collected between the $17^{\text {th }}$ of August and the $16^{\text {th }}$ of November in 2014. Seventy one percent of the participants were female students. The majority of these students were in their second year (45\%) and third year (35\%).

Students' reading interest across the three modes (print, online, social media) was measured with 36 items from reading interest scale developed by Putro (2017), in which the 36 items were converged into 10 factors:

elaboration in print settings, enjoyment in print settings, competence experience in print settings, utility value in online reading, confidence in online reading, enjoyment in online reading, competence experience in online reading, flow in online reading, sense of belonging in social media reading, and enjoyment in social media reading.
In the present study, these 10 factors were referred to as dimensions of reading interest.

The survey items were written in a way that includes a particular reading mode. The survey respondents were asked to rate their interest in reading in three different formats, i.e., reading in print settings, reading online materials, and reading through social media. All items were measured on a 5-point response category, ranging from Strongly Disagree (1) to Strongly Agree (5) with the middle point of Neither Disagree nor Agree (3).

\section{Statistical Analysis}

The main analyses of the present study were confirmatory factor analysis (CFA) and structural equation modeling (SEM). CFA was used to confirm the structure of the reading interest dimensions. SEM was used to test the relationships between the psycho-behavioral constructs of reading interest within and across modes of reading. Mplus version 7.2 (Muthén \& Muthén, 1998-2012) was used for both the CFA and SEM results reported in this study. The maximum likelihood estimation with robust standard errors (MLR) was used to adjust for non-normality of the survey responses of the data, as suggested in Bentler (2005). As the model fit indices, the Comparative Fit Index (CFI > .90), Tucker-Lewis index $($ TLI $>.90)$, Root Mean Square Error of Approximation (RMSEA < .05), and Standardized Root Mean Square Residual (SRMR $<.05)$ were used to indicate a good model fit (criteria cut-off scores indicated, also see Byrne (2006). In addition, a ratio of $1 / 3$ or less between the degrees of freedom $(d f)$ and chi-square statistics $\left(\chi^{2}\right)$ was used as an acceptable model fit criterion (see Wang \& Wang, 2012) instead of the significance of $x^{2}$. The Cronbach's $\alpha$ scale reliability for each factor was calculated with SPSS version 21.

\section{Findings and Discussion}

\section{Nature of Reading Interest}

The result of the confirmatory factor analysis (CFA) showed that the 36 items converged into 10 factors was a very good fit $\left(x^{2}=984.12, \mathrm{df}=549, x^{2} / \mathrm{df}=1.8, \mathrm{RMSEA}=\right.$ $.03, \mathrm{SRMR}=.04, \mathrm{CFI}=.97$, and TLI $=.97$ ). 
Table 1. Confirmatory factor analysis on reading interest

\begin{tabular}{|c|c|c|}
\hline Item & 1 & 2 \\
\hline $\begin{array}{l}\text { 1. I always connect what I read in printed materials to my background } \\
\text { knowledge. }\end{array}$ & .81 & \\
\hline $\begin{array}{l}\text { 2. When I read in printed settings, I always try to understand the } \\
\text { materials better by relating to my personal experiences. }\end{array}$ & .80 & \\
\hline $\begin{array}{l}\text { 3. When I read in printed settings, I always figure out how the } \\
\text { information fits in with what happens in my real life. }\end{array}$ & .78 & \\
\hline 4. I enjoy reading printed materials & & .84 \\
\hline 5. Reading printed materials makes me feel good. & & .77 \\
\hline 6. I feel happy if I receive a printed book as a present. & & .70 \\
\hline 7. I had good marks because I liked reading printed materials. & & \\
\hline $\begin{array}{l}\text { 8. My reading in print settings skill continues to help me get good } \\
\text { grades. }\end{array}$ & & \\
\hline 9. I did well in school due to my ability in reading printed materials. & & \\
\hline
\end{tabular}

11. Reading online materials helps me think about new concepts and ideas.

12. Reading online materials advances my general knowledge.

13. New ideas come to my mind when I read online.

14. I learn about what is going on in the world from reading online materials.

15. Reading online materials makes me feel linked to the world.

16. I obtain a great deal of information whenever do reading online

$4 \quad 56$

7
materials.

17. Reading online materials is very easy for me.

18. I never have problems in reading online materials.

19. When I read from screen (e.g., computer screen, cell-phone, etc.), I am a good reader.

23. I did well in my studies at university because of reading online

24. I did well in school because of my reading online materials ability.

25. I had good grades because I liked reading online materials.

26. My academic achievement has been influenced by my ability in reading online materials.

27. I feel fascinated when I read online.

28. When I read online, I forget about other things.

29. Time goes faster when I read online.

30. I feel linked to others who read the same things from social media sites (e.g. Facebook, WhatsApp).

31. Reading from Social media (e.g. Facebook, WhatsApp) makes me feel connected to the world.

32. Reading from Social media (e.g. Facebook, WhatsApp) makes me

feel belonged to a certain group.

33. Reading from Social media (e.g. Facebook, WhatsApp) makes me communicate better with others.

34. Social media reading is one of my favourite activities (e.g.

Facebook, WhatsApp).

35. Most of the knowledge I obtained is from my social media reading. 36. Once I read social media sites (e.g. Facebook, WhatsApp), I always reading for hours. 
The standardised factor loadings were all significant and substantial, ranging from $\beta=.61$ to $\beta=.91$ across all 36 items. Alpha coefficients for scores on the 10 reading interest dimensions ranged from .76 (enjoyment in social media reading) to .95 (competence experience in online reading), indicating reasonably good internal consistency for each of the scales. The standardized factor loadings of the CFA results are presented in Table 1, together with the Cronbach's $\alpha$ of each factor.

Relationships between the Psycho-behavioral Constructs of Reading Interest

Subsequent to the CFA, the model building strategy was to first construct the model in a way to test the relationships among the psycho-behavioural dimensions situated in a particular mode (e.g., reading online materials). The dimensions representing other modes of reading (i.e., print, mode, and social media) were then added to build a more comprehensive model of reading interest that represented all three models of reading.

\section{Reading Online Materials}

Model A (see Figure 1) was constructed to examine the relationships among the reading interest dimensions within the context of online reading. Because there are more online reading variables (five) than print modes of reading (three) and social media reading (two), the model was built with the dimensions related to online reading first. This model reflects four propositions: (a) enjoyment in reading online materials facilitates flow in online reading (Shernoff, Csikszentmihalyi, Shneider, \& Shernoff, 2003; Sherry, 2004; Csikszentmihalyi, 1997); (b) competence experience in reading online materials is positively linked to enjoyment in online reading (e.g., Carroll \& Loumidis, 2001; Sherry, 2004); (c) confidence in reading online materials is moderately related to enjoyment in online reading (e.g., Clark \& De Zoysa, 2011); and (d) the perceived value in reading online materials is positively related to enjoyment and competence in reading online materials (e.g., Wilson et al., 2008).

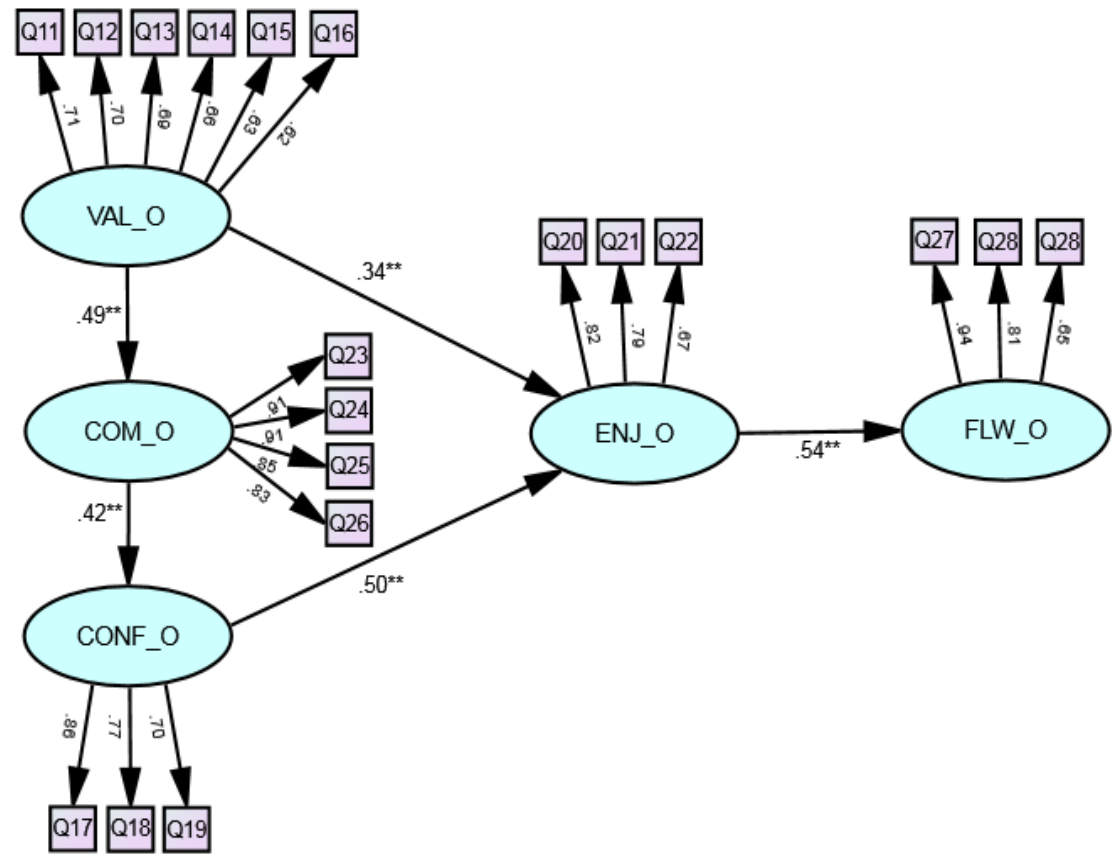

Figure 1. Model A: The relationships among the psycho-behavioural constructs within the context of online reading

Notes: VAL_O: Utility value in online reading; CONF_O: Confidence in online reading; ENJ_O: Enjoyment in online reading; COM_O: Competence experience in online reading; FLW_O: Flow in online reading. 
Table 2. Standardised coefficients, standard errors, estimated standard errors, and p-Value for Model A

\begin{tabular}{lcccc}
\hline \multicolumn{1}{c}{ Path } & Estimate & S.E. & Est./S.E. & Sig. \\
\hline Enjoyment in reading online materials to flow in online reading & .54 & .03 & 16.17 & .00 \\
Utility value in reading online materials to enjoyment in online reading & .34 & .04 & 7.68 & .00 \\
Confidence in reading online materials to enjoyment in online reading & .50 & .05 & 10.79 & .00 \\
$\begin{array}{l}\text { Utility value in reading online materials to competence experience in } \\
\text { online reading }\end{array}$ & .49 & .03 & 14.22 & .00 \\
$\begin{array}{l}\text { Competence experience in reading online materials to confidence in } \\
\text { online reading }\end{array}$ & .42 & .04 & 11.89 & .00 \\
\hline
\end{tabular}

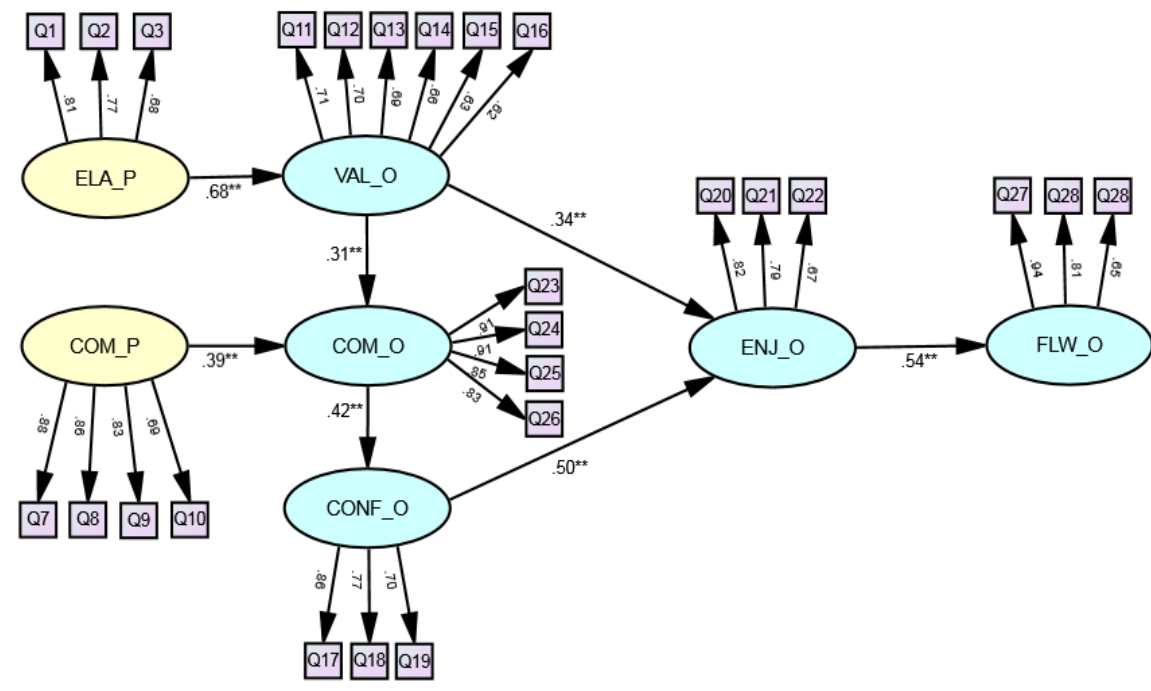

Figure 2. Model B: The relationships among the psycho-behavioural constructs within the context of online reading and reading in print settings

Notes. ELA_P: Elaboration in print settings; ENJ_P: Enjoyment in print settings; COM_P: Competence experience in print settings; VAL_O: Utility value in online reading; CONF_O: Confidence in online reading; ENJ_O: Enjoyment in online reading; COM_O: Competence experience in online reading; FLW_O: Flow in online reading.

Table 3. Standardised path coefficients, etandard errors, estimated standard errors, and p-Value for Model B

\begin{tabular}{|c|c|c|c|c|}
\hline Path & Estimate & S.E. & Est./S.E. & Sig. \\
\hline $\begin{array}{l}\text { Enjoyment in reading online materials to flow in reading online } \\
\text { materials }\end{array}$ & .54 & .03 & 16.14 & .00 \\
\hline $\begin{array}{l}\text { Utility value in reading online materials to enjoyment in online } \\
\text { reading }\end{array}$ & .34 & .04 & 7.84 & .00 \\
\hline $\begin{array}{l}\text { Confidence in reading online materials to enjoyment in online } \\
\text { reading }\end{array}$ & .50 & .05 & 11.06 & .00 \\
\hline $\begin{array}{l}\text { Utility value in reading online materials to competence experience } \\
\text { in online reading }\end{array}$ & .31 & .04 & 8.61 & .00 \\
\hline $\begin{array}{l}\text { Competence experience in reading online materials to confidence in } \\
\text { online reading }\end{array}$ & .42 & .04 & 11.94 & .00 \\
\hline $\begin{array}{l}\text { Competence experience in reading in print to competence } \\
\text { experience in online reading }\end{array}$ & .39 & .04 & 9.95 & .00 \\
\hline Elaboration in reading in print to utility value in online reading & .68 & .03 & 23.16 & .00 \\
\hline
\end{tabular}


The model that showed the best fit to the data is presented in Figure 2. Model B presented in this figure, i.e., Figure 2 yielded good fit $\left(x^{2}=1295.34, \mathrm{df}=577, x^{2} / \mathrm{df}=2.24\right.$, RMSEA $=.04$, SRMR $=.08, \mathrm{CFI}=.95$, and TLI $=.95)$, which are better or higher fit indices compared to those of other models tested. The standardized path coefficients among the seven latent variables were all significant and substantial, ranging from $\beta=.31$ to $\beta=$ .68. In fact, it is an extension of Model A with additional pathways from 'competence in reading in print settings' to 'competence in reading online materials', and from 'elaboration in reading in print settings' to 'utility values in online reading'.

Among the 10 factors, there was one more variable related to reading in print settings, which is 'enjoyment in reading in print settings'. Various attempts were made to include this variable, but the addition of this variable resulted in the worsening of the overall model fit and the potential pathways, such as from 'enjoyment in reading in print settings' to 'enjoyment in online reading' $(\beta=$ $.16, p<.01)$ and from 'enjoyment in reading in print settings' to 'flow in online reading' $\beta$
$=.03, p>.05)$, showed weak and non-significant links. Therefore, the variable was dropped in the final model, and it was concluded that Model B is the best representation of the variables related to two reading settings (i.e., print and online reading). It also shows that reading interest in print settings precedes interest in reading online materials

Reading online materials, social media reading, and reading in print settings

Model C (see Figure 3) was constructed to examine the relationships among the reading interest dimensions from the three different types of reading modes (i.e., reading online materials, reading in print settings, and social media reading). Out the 10 factors, two variables are related to reading in social media, enjoyment in social media reading and sense of belonging through social media reading. Models were built to reflect the literature suggesting that: (a) confidence in reading is moderately related to enjoyment in reading (e.g., Clark \& De Zoysa, 2011; McGeown et al., 2015) and (b) elaboration is related to sense of belonging (e.g., Sundar, 2015).

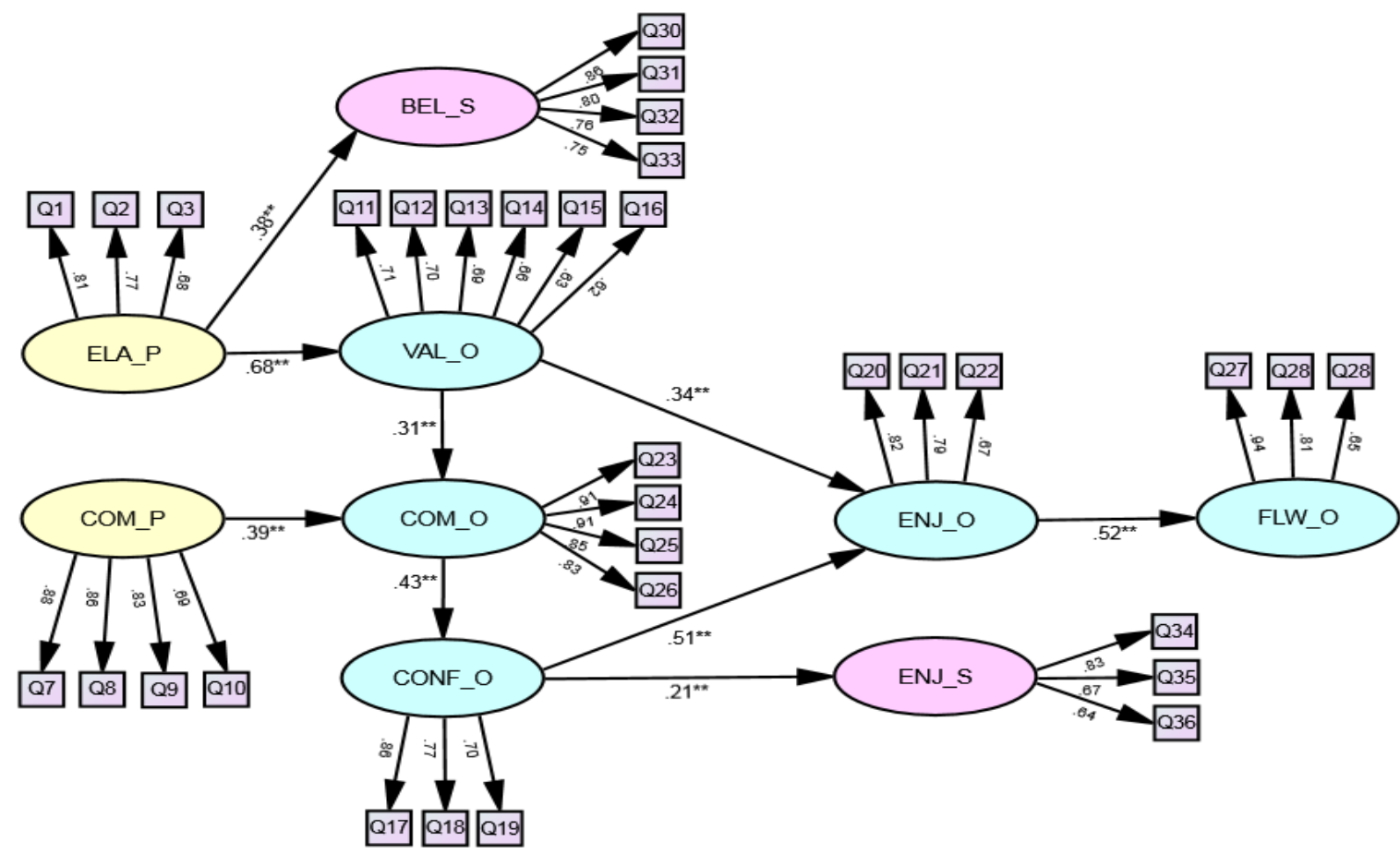

Figure 3. Model C: The relationships among the psycho-behavioural constructs of interest in online reading, social media reading, and reading in print settings 
Notes: ELA_P: Elaboration in print settings; ENJ_P: Enjoyment in print settings; COM_P: Competence experience in print settings; VAL_O: Utility value in online reading; CONF_O: Confidence in online reading; ENJ_O: Enjoyment in online reading; COM_O: Competence experience in online reading; FLW_O: Flow in online reading; BEL_S: Sense of belonging in social media reading; ENJ_S: Enjoyment in social media reading.

Table 4. Standardised path coefficients, standard errors, estimated standard errors, and p-Value of Model C

\begin{tabular}{lcccc}
\multicolumn{1}{c}{ Path } & Estimate & S.E. & Est./S.E. & Sig. \\
\hline $\begin{array}{l}\text { Enjoyment in reading online materials to flow in reading } \\
\text { Online materials }\end{array}$ & .52 & .03 & 15.16 & .00 \\
$\begin{array}{l}\text { Utility value in reading online materials to enjoyment in } \\
\text { online reading }\end{array}$ & .33 & .04 & 7.65 & .00 \\
$\begin{array}{l}\text { Confidence in reading online materials to enjoyment in } \\
\text { online reading }\end{array}$ & .51 & .05 & 11.18 & .00 \\
$\begin{array}{l}\text { Utility value in reading online materials to competence } \\
\text { experience in online reading }\end{array}$ & .31 & .04 & 8.64 & .00 \\
$\begin{array}{l}\text { Competence experience in reading online materials to } \\
\text { confidence in online reading }\end{array}$ & .43 & .04 & 12.04 & .00 \\
$\begin{array}{l}\text { Competence experience in reading in print to } \\
\text { competence experience in online reading }\end{array}$ & .39 & .04 & 10.12 & .00 \\
$\begin{array}{l}\text { Elaboration in reading in print to utility value in online } \\
\text { reading }\end{array}$ & .72 & .03 & 26.00 & .00 \\
$\begin{array}{l}\text { Elaboration in reading in print to sense of belonging in } \\
\text { social media reading }\end{array}$ & .41 & .04 & 10.25 & .00 \\
$\begin{array}{l}\text { Confidence in online reading to enjoyment in social } \\
\text { media }\end{array}$ & .22 & .50 & 4.53 & .00 \\
\hline
\end{tabular}

After several options were tested, a final model was chosen in which 'elaboration in print settings' is significantly related to 'sense of belonging in social media reading' $(\beta=.41$, $p<.01)$ and 'confidence in online reading' is significantly linked to 'enjoyment in social media' $(\beta=.22, p<.01)$. Model $\mathrm{C}$ yielded good fit $\left(\chi^{2}=1292.38, \mathrm{df}=579, \chi^{2} / \mathrm{df}=2.23\right.$, RMSEA $=.04$, SRMR $=.08$, CFI $=.95$, and TLI $=.95)$. The standardised path coefficients in Model $\mathrm{C}$ were all significant and substantial, ranging from $\beta=.21$ to $\beta=.68$ across all nine latent variables. This model reveals weak to moderate relationships between interest in social media reading and interest in reading online materials and printed materials. Table 4 shows the standardised parameter estimates and standard errors of all pathways included in Model C.

\section{Discussion}

Despite extensive research on reading interest, the relationships among the psychobehavioral dimensions of that construct remain unclear. The aim of this study is to ex- amine how the dimensions of reading interest within and across modes of reading are related to one another. Noteworthy findings from the final models of the relationship among the dimensions of reading interest are considered in this section.

The first important finding is that the dimensions of interest in reading in print settings preceded those of interest in reading online materials, suggesting the importance of interest in reading in print settings for the development of interest in reading online materials. This finding supports the idea that reading in print settings is positively linked to, or may even facilitate, reading online materials (e.g., Coiro, 2011a, 2011b; Coiro \& Dobler, 2007; Schmar-Dobler, 2003). It may partly be explained by the fact that, to be able to get the most from reading online materials, readers need to be proficient in reading in print settings and to be able to use their reading-inprint strategies in order to read in online settings. Fluent in-print readers need to learn additional practices and strategies, such as how to use web-based search engines and how to locate information efficiently and 
effectively by adopting strategies they used when they read in print settings. To better understand what they read online, undergraduate students also need to connect what they already know from reading in print settings to what they read online.

In contrast to earlier findings (e.g., De Waal et al., 2005; Mokhtari et al., 2009), however, this study found no evidence of negative relationships between interest in reading online materials and interest in reading in print settings. A possible explanation for this is that previous studies relied on the frequency of either reading online materials or reading in print settings as the measure of reading interest. These previous studies drew this conclusion (i.e., that there is a negative relationship between reading online materials and reading in print) based on the fact that the time individuals spent reading online materials reduced the time they spent reading printed materials because they could not use the time spent on one activity for time spent on another activity (see Mokhtari et al., 2009; Valkenburg \& Peter, 2007). This study, however, did not rely on frequency of reading as the measure of reading interest, which might account for the different results.

A moderate relationship between elaboration in reading in print settings and sense of belonging in social media reading was also documented in this study. This relationship may partly be explained by the nature of social media reading itself; that is, an activity performed to establish interactions among readers who share a common interest. The source of this interest may be what they read in print settings (e.g., interest in reading printed novels or comics). This result supports previous research findings that reading in print settings is related to social media reading (e.g., Cheung, Chiu, \& Lee, 2011; Tenopir et al., 2013). The particular relationship between elaboration and sense of belonging has also been documented by Sundar (2015).

Third, considering the relationships between particular reading interest dimensions, the first important finding is that enjoyment in reading seems to be the only variable directly and consistently connected to flow in reading. In the three models $(\mathrm{A}, \mathrm{B}$, and $\mathrm{C})$, it is evident that enjoyment is the sole predictor of flow across modes of reading. This result appears to be consistent with other research showing that flow occurred only when individuals continued to follow their sense of enjoyment in a particular object of interest (Csikszentmihalyi, 1997; Shernoff et al., 2003). A possible explanation for this is that the flow experience in reading occurs only when an individual finds the reading activity to be intrinsically enjoyable. Thus, people who know the value of the reading material and are confident in their reading skills will not experience flow if they do not find the reading activity enjoyable. This finding has important implications for the use of enjoyment in reading as one of the key predictors of flow in reading in future measurement of reading interest.

This study also found that utility value in reading was significantly connected to enjoyment in reading online materials. This result is in line with those in previous studies (e.g., Nakamura \& Csikszentmihalyi, 2009; Wilson et al., 2008) and may help us to understand why some students are reluctant to read when they cannot perceive the value of what they need to read. This result may be explained by the fact that people find a reading activity enjoyable when they believe the reading activity is valuable or worth doing. In other words, the value or benefits expected from reading a text may help the reader to find the reading activity pleasurable.

Another interesting finding is that enjoyment in reading online materials is significantly linked to confidence in reading online materials and that confidence in reading online materials is significantly predicted by competence experience in reading online materials. This result supports the idea that enjoyment in reading is strongly influenced by both competence and confidence in reading (e.g., Clark \& De Zoysa, 2011). It may explain the relatively significant correlation among confidence, competence, and enjoyment in the way that improvement in individuals' competence in reading leads to improvement in their confidence in reading. Improvement in their confidence may in turn lead to an increase in the pleasure or enjoyment derived from reading, as individuals will only find the 
activity enjoyable when they are confident that their skills meet the associated reading challenges (Shernoff et al., 2003).

The results of this study also show that elaboration in reading is strongly connected with both utility value in reading online materials and enjoyment in recreational reading. This result is consistent with findings from other studies that elaboration is moderately related to enjoyment (e.g., Frenzel, Goetz, Stephens, \& Jacob, 2009) and utility value (e.g., Brockman, 2006). One possible reason for this is that linking individuals' prior knowledge with what they are reading facilitates the creation of a balance between what they already know and the challenge from the reading process. In turn, this leads them to perceive the reading activity as enjoyable and the activity as valuable or worth doing. These findings suggest that, to help learners get the most from what they read, teachers need to involve the students' prior knowledge before gradually changing the level of reading challenge to help them enjoy the reading process and to recognize the value of what they read.

This study also found a significantly weak relationship between confidence in reading online materials and enjoyment in social media reading. This result supports the ideas of Dunst and Dempsey (2007) who found that confidence in parenting led to enjoyment in parenting. Further, research has shown that confidence in reading is moderately related to enjoyment in reading (McGeown et al., 2015). This relationship may be partly explained by the fact that when people believe they are good at a particular activity (i.e. confident in their abilities), they are more likely to enjoy performing the activity (Boyd \& Yin, 1996; Carroll \& Loumidis, 2001; Durik, Vida, \& Eccles, 2006). Thus, undergraduate students' belief in their abilities in reading online materials appears to lead them to enjoy reading through social media platforms such as Facebook and Twitter.

\section{Conclusion and Suggestions}

This study provides evidence of how the psycho-behavioral constructs of reading interest are related to one another. Given that the constructs within interest in reading in print settings are connected to those in reading online materials, educators need to encourage students utilizing both reading modes to help them get the best from their reading. Online materials help students search for information efficiently and effectively, whereas printed materials facilitate deep understanding. The existence of moderate to strong relationships among elaboration in reading in print settings, utility value in reading online materials, confidence in reading online materials, and enjoyment in reading online materials suggests that educators can enhance students' reading interest (particularly their enjoyment in reading) by connecting reading tasks to real life experience, assigning value to the reading activity, and developing students' confidence in reading.

Although testing of the final model of reading interest dimensions yielded an acceptable fit with the data, other models might also yield an acceptable fit. Evidence from other types of investigations is required to confirm these models and to test their application.

\section{References}

Alterman, E. (2007). Out of print: The death and life of the American newspaper. Caligrama (São Paulo. Online), 3(3). doi: http://dx.doi.org/10.11606/issn.18080820.cali.2007.67395.

Bentler, P. M. (2005). EQS 6 structural equations program manual. Encino, CA: Multivariate Software, Inc.

Boyd, M. P., \& Yin, Z. (1996). Cognitiveaffective sources of sport enjoyment in adolescent sport participants. Adolescence, 31(122), 383-395.

Brockman, G. (2006). What factors influence achievement in remedial mathematics classes? (Doctoral dissertation). University of Southern California, Los Angeles, CA.

Buzzetto-More, N., Guy, R., \& Elobaid, M. (2007). Reading in a digital age: Ebooks are students ready for this learning object? Interdisciplinary Journal of $E$ Learning and Learning Objects, 3, 239-250.

Byrne, B. M. (2006). Structural equation modeling with EQS: Basic concepts, applications, and 
programming: Mahwah, NJ: Lawrence Erlbaum Associates.

Carroll, B., \& Loumidis, J. (2001). Children's perceived competence and enjoyment in physical education and physical activity outside school. European Physical Education Review, 7(1), 24-43. doi: https://doi.org/10.1177/1356336X010 071005

Cheung, C. M., Chiu, P.-Y., \& Lee, M. K. (2011). Online social networks: Why do students use Facebook?. Computers in Human Behavior, 27(4), 1337-1343. doi: 10.1016/j.chb.2010.07.028

Chouinard, R., Karsenti, T., \& Roy, N. (2007). Relations among competence beliefs, utility value, achievement goals, and effort in mathematics. British Journal of Educational Psychology, 77(3), 501-517. doi: 10.1348/000709906X133589

Clanton, J., Gardner, A., Cheung, M., Mellert, L., Evancho-Chapman, M., \& George, R. L. (2014). The relationship between confidence and competence in the development of surgical skills. Journal of Surgical Education, 71(3), 405-412. doi: 10.1016/j.jsurg.2013.08.009

Clark, C., \& De Zoysa, S. (2011). Mapping the interrelationships of reading enjoyment, attitudes, behaviour and attainment: An exploratory investigation. London: National Literacy Trust.

Cocks, R. J., \& Watt, H. M. (2004). Relationships among perceived competence, intrinsic value and mastery goal orientation in English and maths. The Australian Educational Researcher, 31(2), 81-111. doi: 10.1007/BF03249521.

Coiro, J. (2011a). Predicting reading comprehension on the Internet: Contributions of offline reading skills, online reading skills, and prior knowledge. Journal of Literacy Research, 43(4), 352-392. doi: $10.1177 / 1086296 \times 11421979$

Coiro, J. (2011b). Talking about reading as thinking: Modeling the hidden complexities of online reading comprehen- sion. Theory Into Practice, 50(2), 107-115. doi: 10.1080/00405841.2011.558435

Coiro, J., \& Dobler, E. (2007). Exploring the online reading comprehension strategies used by sixth-grade skilled readers to search for and locate information Internet. Reading Research Quarterly, 42(2), 214-257. doi: 10.1598/RRQ.42.2.2

Csikszentmihalyi, M. (1997). Flow and the psychology of discovery and invention. New York, NY: Harper Collins.

DeWaal, E., Schönbach, K., \& Lauf, E. (2005). Online newspapers: A substitute or complement for print newspapers and other information channels? Communications, 30(1), 55-72. doi: 10.1515/comm.2005.30.1.55

Dunst, C. J., \& Dempsey, I. (2007). Familyprofessional partnerships and parenting competence, confidence, and enjoyment. International Journal of Disability, Development and Education, 54(3), 305318. doi: $0.1080 / 10349120701488772$

Durik, A. M., Vida, M., \& Eccles, J. S. (2006). Task values and ability beliefs as predictors of high school literacy choices: A developmental analysis. Journal of Educational Psychology, 98(2), 382-393. doi: 10.1037/0022-0663.98.2.382.

Eccles, J. S. (1983). Expectancies, values, and academic behaviors. In J. Spence (Ed.), Achievement and achievement motives: Psychological and sociological approaches (pp. 75-146). San Francisco, CA: Freeman.

Frenzel, A. C., Goetz, T., Stephens, E. J., \& Jacob, B. (2009). Antecedents and effects of teachers' emotional experiences: An integrated perspective and empirical test. In P. Schutz (Ed.), Advances in teacher emotion research: The impact on teachers' lives (pp. 129-151). Dordrecht: Springer.

Junco, R. (2012). Too much face and not enough books: The relationship between multiple indices of Facebook use and academic performance. Computers in Human Behavior, 28(1), 187-198. doi: 10.1016/j.chb.2011.08.026 
Karim, N. S. A., \& Hasan, A. (2007). Reading habits and attitude in the digital age. The Electronic Library, 25(3), 285-298. doi: 10.1108/02640470710754805

Kirchhoff, S. M. (2010, September). US newspaper industry in transition. Paper presented in Congressional Research Service Report for Congress.

Kirschner, P. A., \& Karpinski, A. C. (2010). Facebook ${ }^{\circledR}$ and academic performance. Computers in Human Behavior, 26(6), 1237-1245. doi: https://doi.org/ 10.1016/j.chb.2010.03.024

Lau, K.-1., \& Ho, E. S.-c. (2016). Reading performance and self-regulated learning of Hong Kong students: What we learnt from PISA 2009. The Asia-Pacific Education Researcher, 25(1), 159-171. doi: https://doi.org/10.1007/s40299-0150246-1.

Lee, P. S., \& Leung, L. (2008). Assessing the displacement effects of the Internet. Telematics and Informatics, 25(3), 145-155. doi: 10.1016/j.tele.2006.08.002

Liu, Z. (2005). Reading behavior in the digital environment: Changes in reading behavior over the past ten years. Journal of Documentation, 61(6), 700-712. doi: 10.1108/00220410510632040

Liu, Z., \& Huang, X. (2008). Gender differences in the online reading environment. Journal of Documentation, 64(4), 616-626. doi: http://dx.doi.org/ 10.1108/00220410810884101

Marsh, H. W., \& Martin, A. J. (2011). Academic self-concept and academic achievement: Relations and causal ordering. British Journal of Educational Psychology, 81(1), 59-77. doi: 10.1348/000709910X503501

McGeown, S. P., Johnston, R. S., Walker, J., Howatson, K., Stockburn, A., \& Dufton, P. (2015). The relationship between young children's enjoyment of learning to read, reading attitudes, confidence and attainment. Educational Research, 57(4), 389-402. doi: 10.1080/00131881.2015.1091234
McKenna, M. C., Conradi, K., Lawrence, C., Jang, B. G., \& Meyer, J. P. (2012). Reading attitudes of middle school students: Results of a U.S. survey. Reading Research Quarterly, 47(3), 283306. doi: $10.1002 /$ rrq.021

Mokhtari, K., Reichard, C. A., \& Gardner, A. (2009). The impact of internet and television use on the reading habits and practices of college students. Journal of Adolescent \& Adult Literacy, 52(7), 609619. doi: 10.1598/JAAL.52.7.6

Muthén, L. K., \& Muthén, B. O. (1998-2012). Mplus User's Guide (7th ed.). Los Angeles, CA: Muthén \& Muthén.

Nakamura, J., \& Csikszentmihalyi, M. (2009). The concept of flow. In C. R. Snyder \& S.J. Lopez, Oxford Handbook of Positive Psychology (pp. 89-105). New York, NY: Oxford University Press.

OECD. (2011). PISA 2009 results: Students on line: Digital technologies and performance (Vol. 6). Paris: OECD Publishing.

Pajares, F., \& Johnson, M. J. (1994). Confidence and competence in writing: The role of self-efficacy, outcome expectancy, and apprehension. Research in the Teaching of English, 28(3), 313-331. doi: $10.2307 / 40171341$.

Perry, R. P., \& Smart, J. C. (2007). The scholarship of teaching and learning in bigher education: An evidence-based perspective. Dordrecht: Springer Science \& Business Media.

Putro, N. (2017). Reading interest in a digital age (Doctoral dissertation). University of New South Wales, Sydney.

Schleicher, A. (2016). Teaching excellence through professional learning and policy reform: Lessons from around the world. International summit on the teaching profession. OECD Publishing. doi: 10.1789/9789264252059.en

Schmar-Dobler, E. (2003). Reading on the Internet: The link between literacy and technology. Journal of Adolescent \& Adult 
Literacy, $\quad 47(1)$, $10.2307 / 40026906$

80-85.

doi:

Shernoff, D. J., Csikszentmihalyi, M., Shneider, B., \& Shernoff, E. S. (2003). Student engagement in high school classrooms from the perspective of flow theory. School Psychology Quarterly, 18(2), 158-176. doi: 10.1521/scpq.18.2.158.21860

Sherry, J. L. (2004). Flow and media enjoyment. Communication Theory, 14(4), 328-347.

Stankov, L., \& Lee, J. (2008). Confidence and cognitive test performance. Journal of Educational Psychology, 100(4), 961-976. doi: $10.1037 / \mathrm{a} 0012546$

Sundar, S. S. (2015). The bandbook of the psychology of communication technology. Chicester: John Wiley \& Sons. http://unsw.eblib.com/patron/FullRec ord.aspx?p $=1895448$

Tenopir, C., Volentine, R., \& King, D. W. (2013). Social media and scholarly reading. Online Information Review, 37(2), 193216. doi: 10.1108/OIR-04-2012-0062

Valkenburg, P. M., \& Peter, J. (2007). Online communication and adolescent wellbeing: Testing the stimulation versus the displacement hypothesis. Journal of Computer-Mediated Communication, 12(4), 1169-1182. doi: 10.1111/j.10836101.2007.00368.x

Veenhof, B. (2006). The Internet: Is it changing the way Canadians spend their time? Statistics Canada. Available at http://www.statcan.gc.ca/pub/56f0004 $\mathrm{m} / 56$ f0004m2006013-eng.htm.

Walsh, M. (2010). Multimodal literacy: What does it mean for classroom practice? Australian Journal of Language and Literacy, 33(3), 211-239.
Wang, J., \& Wang, X. (2012). Structural equation modeling: Applications using Mplus. Chicester: John Wiley \& Sons.

Weber, R., Tamborini, R., Westcott-Baker, A., \& Kantor, B. (2009). Theorizing flow and media enjoyment as cognitive synchronization of attentional and reward networks. Communication Theory, 19(4), 397-422. doi: 10.1111/j.14682885.2009.01352.x

Wigfield, A. (1994). Expectancy-value theory of achievement motivation: A developmental perspective. Educational Psychology Review, 6(1), 49-78. doi: $10.2307 / 23359359$

Wigfield, A., \& Eccles, J. S. (2002). The development of competence beliefs, expectancies for success, and achievement values from childhood through adolescence. In A. Wigfield, \& J. Eccles (Eds.), The development of achievement motivation (pp. 91-120). San Diego, CA: Academic Press. doi: https://doi.org/10.1016/B978012750053-9/50006-1

Wigfield, A., \& Tonks, S. (2002). Adolescents' expectancies for success and achievement task values during the middle and high school years. In $\mathrm{T}$. Urdan \& F. Pajares (Eds.), Academic motivation of adolescents (pp. 53-82). Greenwich, CT: Information Age.

Wilson, N., Bouhuijs, P., Conradie, H., Reuter, H., Van Heerden, B., \& Marais, B. (2008). Perceived educational value and enjoyment of a rural clinical rotation for medical students. Rural Remote Health, 8(3), 999. Available at: http://www.rrh.org.au/articles/subvie wnew.asp?ArticleID=999. 